\title{
O leksiki s slovarsko-slovničnega vidika v smislu 'od besede do slovarja' (Branka Tafra: Od riječi do rječnika, Zagreb 2005)
}

\author{
Andreja Žele
}

IZVLEČEK: Monografija priznane hrvaške jezikoslovke in predvsem pa izkušene leksikografinje Branke Tafra obsega dvajset avtoričinih razprav iz zadnjih desetih let. Že v kratkem nagovoru na platnicah knjige avtorica poudarja, da monografija obravnava besedo predvsem s slovničnega in leksikološko-leksikografskega vidika, kar omogoča čimbolj celostno slovnično in pomensko predstavitev besed oz. leksemov v slovarjih.

Grammatical and Lexicographic Aspects of Vocabulary in the Sense of "from Lexeme to Lexicon"

(Branka Tafra: Od riječi do rječnika (From Lexeme to Lexicon), Zagreb 2005)

ABSTRACT: This monograph by Branka Tafra, a recognized Croatian linguist and experienced lexicographer, comprises twenty of her articles from past decades. In a short note on the cover itself, the author emphasizes that this volume deals with words primarily from the grammatical and lexicological/lexicographic point of view, making possible the most comprehensive grammatical and semantic presentation of words, or lexemes, in dictionaries.

Monografija priznane hrvaške jezikoslovke in predvsem izkušene leksikografinje Branke Tafra obsega dvajset avtoričinih razprav iz zadnjih desetih let (naslovi in podrobnejši bibliografski podatki o teh razpravah so navedeni v začetnem vsebinskem kazalu (7) in še prav na koncu v posebnem popisu bibliografskih podatkov samo za teh dvajset vključenih razprav (317-318)). Že v kratkem nagovoru na platnicah knjige avtorica poudarja, da monografija obravnava besedo predvsem s slovničnega in leksikološko-leksikografskega vidika, kar omogoča čimbolj celostno slovnično in pomensko predstavitev besed oz. leksemov v slovarjih.

Pred seboj imamo še eno potrditev logične in samoumevne vzajemne soodvisnosti in prepletenosti slovnice in slovarja (t. i. teorija integralnega opisa jezika po Ju. Apresjanu) - razprave z vidika praktične leksikološko-leksikografske obdelave dajejo primere in hkrati predloge za slovaropisno obravnavo posameznih slovničnih in pomenskih kategorij kot so npr. spol, oseba, števnost pa enako- oz. blizupomenke 
v okvirih sinonimije in blizu- oz. enakozvočnice v okvirih paro- in homonimije, pa razmerje med polisemijo in homonimijo.

V obravnavi posameznih možnih slovarskih rešitev so vzporedno ob posameznih primerih (vsaj posredno) ovrednoteni konkretni slovarji, predvsem hrvaški. Zelo pozitivno je s posameznimi primeri slovarskih rešitev ovrednoten Slovar slovenskega knjižnega jezika (SSKJ). Sicer pa se avtorica pri opredelitvah in še zlasti pri utemeljitvah sklicuje tudi na mednarodno priznane jezikoslovne in leksikološke avtoritete kot so npr. Ju. D. Apresjan, J. Filipec, F. Čermák, I. A. Mel'čuk, L. Zgusta, A. A. Zaliznjak, A. Wierzbicka. Našteti avtorji so vsi razvijali in dopolnjevali teorijo semantičnih prototipov (to so neke vrste pomenski primitivi) in vzporedno $\mathrm{s}$ to še teorijo leksikografskih tipov.

\section{Glavna opozorila in napotki, koristni za slovaropisno delo}

$\mathrm{Na}$ osnovi problemsko-kritičnega pregleda aktualnih hrvaških razlagalnih slovarjev (prim. V. Anić, Rječnik hrvatskoga jezika (Zg. 1991, 1994, 1998, 2003) in Rječnik hrvatkoga jezika LZ-ŠK /Leksikografski zavod-Školska knjiga/, ur. J. Šonje, Zg. 2000) avtorica opozarja na najpogostejše napake in pomanjkljivosti:

1 Leksikografija je $\mathrm{v}$ primerjavi $\mathrm{z}$ drugim jezikoslovjem praviloma počasnejša pri sprejemanju novih jezikoslovnih spoznanj in zato posledično konservativnejša. In če je slovnica postavlja splošna pravila in sploh išče splošnoveljavnejše/posplošene jeziko(slo)vne zakonitosti, pa mora slovar beležiti vse posebnosti in odmike od sistemsko že vključenih in določenih jezikovnih sestavin. In čeprav je zaželeno leksikografovo dobro in široko jezikoslovno znanje in je pri izdelavi geselskega članka hkrati skoraj nepogrešljiv tudi njegov jezikovni čut, morajo biti pred začetkom redakcijskega dela dovolj trdno teoretično postavljena leksikološko-leksikografska merila za vse faze izdelave slovarja - slovar mora namreč kot rezultat navadno skupinskega dela delovati kot homogena celota.

V procesu slovaropisnega dela leksikografa lahko zavaja prevelika subjektivizacija nekaterih meril - tako lahko s preskopim okvalificiranjem in razlaganjem leksemov naslovnika oz. uporabnika slovarja precenjuje, po drugi strani pa si zaradi pomanjkanja gradivnih zgledov lahko pri redakciji geselskega članka vzame prevelike jeziko(slo)ne kompetence; oboje sta leksikografski napaki.

V okviru običajne informativno-normativne vloge slovarja, naj bo absolutno težišče na informativnosti (tako pomenski kot slovnični), medtem ko se lahko normativnost $\mathrm{z}$ vzporednimi dogovori postopoma uresničuje.

1.1 Z vidika kakršnih koli odmikov od jeziko(slo)vnega sistema lahko govorimo tudi o manjsistemskih oz. nesistemskih besednih vrstah - po B. Tafri so to »nepravilnici« (67) oz. slovenjeno lahko tudi 'nepravilnice' npr. tipa nesklonljivih pridevnikov, ki so zaradi prilastkovne in povedkovodoločilne vloge (kljub oblikoslovnim pomanjkljivostim) po načelu, da ustaljene skladenjskopomenske kategorialne lastnosti lahko postanejo kategorialne pomenske sestavine besednih vrst, pridevniške besede; po merilu skladenjskopomenskih vlog oz. lastnosti lahko števniki sodijo enkrat med pridevniške besede, drugič med samostalniške ali pa med prislove. 


\section{Jezikovna in izvenjezikovna stvarnost}

2.1 Ločevanje jezikovne in izvenjezikovne stvarnosti se lepo odraža v ločevanju naravnega in slovničnega spola ( $\mathrm{v}$ hrv. spol : rod), oseba $\mathrm{v}$ denotativnem pomenu nasproti osebi kot slovnični (glagolski) kategoriji (v hrv. oseba : lice).

Slovar ima po mnenju avtorice nedvomno lepo možnost jasno ločevati slovnični spol kot vrsto sklanjatve od naravnega spola. Ugotavlja tudi, da niti v enem jeziku motiviranost slovničnega spola z naravnim spolom ni popolna, tako npr. mlada moška ali ženska bitja lahko imajo vse tri slovnične spole, npr. fant, dekle, fante, nasproti pa slovnični spol pri dete lahko pomeni dečka ali deklico ipd. Posebna skupina, ki ne izraža soodvisnosti naravnega in slovničnega spola, so čustvenostno zaznamovana poimenovanja tipa baraba, jetika, barbika ipd. Primeri kot množinska ta skripta (v stranskih sklonih oblike srednjega ali ženskega spola) in edninski ta vodja (v stranskih sklonih oblike moškega ali ženskega spola) dokazujejo, da osnovna oblika ne izraža nujno vse možne v konkretni izraz vključene slovnične spole.

2.2 Prepogosto je premalo uzaveščeno ločevanje med slovnično kategorijo števila in pomensko kategorijo števnosti od izvenjezikovne zmožnosti štetja predmetnosti.

Poleg glede na številskost oz. na oblikoslovno zmožnost pregibanja po številih že ločevanih samoedninskih in samomnožinskih besed (singularia tantum in pluralia tantum) tipa kdo, vrata je treba dodatno slovarsko označiti besede, ki se navadno najpogosteje uporabljajo v množini, npr. agrumi, arašidi, barvice, bezgavke. Posebnost glede na števnost so $\mathrm{v}$ smislu količine neštevna skupinska, pojmovna in snovna imena tipa listje, grmovje, gospoda, lepota, moka, kjer se z ločilnimi števniki izraža različnost štetega. Pri razmerju slovnična raba nasproti pomenska raba imajo vrata slovnično množino in pomensko ednino, listje pa ima slovnično ednino in pomensko množino ipd. S pomensko-slovničnega vidika so uzaveščena tudi razmerja list : listi : listje, namreč zelo redko so slovnične kategorije tudi leksikalno izražene, npr. jaz : mi, človek : ljudje.

Slovarnik tudi mora ločevati med npr. dvoji čevlji in dvoje čevljev, dvoja vrata in dvoje vrat, dvoje hlače in dvoje nogavice, dvoji ljudje ipd.

Pomensko je $d v a$ je kvantifikator, oba pa je kvantifikator in totalizator obenem, in še dva moža (nepoznano) in oba moža (poznano).

2.3 V okviru leksemske enote bi se morale z zgledi izraziti vse slovnične spremembe oz. odstopanja, npr. pri glagolskih geslih možnost tretjeosebne rabe, npr. iti, padati v Dež gre/pada, pomenske razlike pri uporabi morfema se, npr. v On smuča : On se sтис̆a, vezljivostne spremembe tipa Vrnil se je : Vrnil se je proti večeru: Vrnil se je domov : Vrnil se je na stari dom ipd., slovarsko je skoraj nujno, da so produktivna predponska obrazila obravnavana kot samostojne slovarske iztočnice.

Avtorica ugotavlja, da se skladno s tradicionalnim slovaropisjem še vedno daje prednost enobesednim leksikalnim enotam.

3 Treba je slovarsko ločevati opisne/kakovostne pridevnike od razmernih/vrstnih pridevnikov tudi kot dva ločena tipa pridevniških iztočnic, tudi v slovenščini 
je npr. problemsko izpostavljeno predvsem razmerje med pridevniškima obraziloma -(e)n : -ni za primere zračen prostor : zračni tok.

4 Pri sestavljanju slovarskega geslovnika se vedno znova pojavlja eno temeljnih vprašanj, in sicer katere so tiste pomensko-slovnične postavke, ki odločajo o leksemski polisemiji in o njenem razpadu na več samostojnih leksemov in še o možni leksikalizaciji ali konverziji.

4.1 Leksikalna večpomenskost lahko povzroči tudi slovnično večpomenskost, npr. ko se sicer števna beseda $v$ določenem pomenu lahko samomnožinsko uporablja, prim. lisice, okovi (nasproti vile/vila v SSKJ); v SSKJ ni npr. opozorjeno na razmerje skok : skoki); za hrvaščino avtorica navaja slovnično-pomensko razmerje števnosti izbor : izbori 'volitve', ki zahteva dve slovarski izročnici.

4.2 Pomembno je ločevati polisemijo od konverzije - pri konverziji gre za nastanek nove besede oz. leksema, in ne zgolj za širjenje polisemije. Avtorica še posebej eksplicitno pohvali rešitev SSKJ-ja, ki jaz mene in jaz, jaza pomenskoslovnično ločuje kot samostojni gesli. Precej jezikoslovcev konverzijo obravnava kot možen način nastajanja homonimije, vendar sta konverzija in homonim zlasti istopisnici, ker že en skupni sem med konverzijo in njenim izhodiščnim leksemom preprečuje njuno homonimno razmerje. Proces, ki vodi k novemu slovarskemu geslu kot novi leksemski enoti, gre v smeri degramatikalizacija > leksikalizacija > konverzija (117).

4.3 Širjenje polisemizacije je, ko se novo predmetnost ali pojavnost poimenuje z že obstoječo in rabljeno besedo oz. izrazom; s preširoko polisemizacijo se v naslednji stopnji nekateri pomeni začnejo osamosvajati, tj. nastopi depolisemizacija in hkrati z njo možnost nove homonimizacije, kar lahko poenostavimo s smerjo poteka razširjena polisemizacija $>$ depolisemizacija $>$ homonimizacija; vedno pa med polisemijo in homonimijo ostaja precej nerešenih vmesnih primerov, saj se medleksemski odnosi nenehno bolj ali manj spreminjajo.

$\mathrm{S}$ širjenjem polisemizacije moramo omeniti tudi izraze, ki so zaradi prepogoste in posledično napačne uporabe pomensko izrabljani, zaradi tega tudi pomensko izpraznjeni - Tafra jih označuje kot »izrabljenice« (203), kot slovensko ustreznico pa uporabljam izraz razpomenke. Pogoste t. i. razpomenke so internacionalizmi kot kvaliteta (ki se navadno napačno uporablja samo za označevanje pozitivnih lastnosti), material, problem, sektor, relativno, absolutno, definitivno ipd.

4.4 $\mathrm{Z}$ vidika sinonimije $\mathrm{v}$ jeziku prevladujejo t. i. lažni sinonimi, kajti absolutna pomenska identičnost (z istim denotatom) je redka, več je t. i. velike podobnosti »smislov«, ki jo avtorica označuje z »blizusinonimijo«, podobnopomenke pa se uvrščajo v »similisemijo«. Pri prepoznavanju sinonimije velja nekaj temeljnih meril - 1) sinonimi so lahko samo izrazi znotraj istih besednih vrst, kar jim med drugim omogoča zamenljivost $\mathrm{v}$ vseh sobesedilih, 2) o sinonimiji lahko govorimo samo $\mathrm{v}$ okvirih istega jezika, 3) sinonimija je vprašljiva tudi med izrazi iz različnih socialnih in funkcijskih zvrsti, 4) pri ugotavljanju sinonimije se ne sme mešati diahronih in sinhronih izhodišč; iz naštetega avtorica povzema, da prostorska in časovna razslojenost leksike zožuje oz. manjša sinonimijske/z/možnosti, medtem ko stilska razslojenost $\mathrm{v}$ standardnem jeziku ne bi smela ovirati sinonimnih razmerij. 
V nadaljevanju avtorica po M. Samardžiji povzema merila za blizupomenke označuje jih kot sinonime, ki so omejeno zamenljivi samo v določenih sobesedilih, ki imajo lahko različno široko pomenskost in ki lahko pripadajo različnim socialnofunkcijskim zvrstem jezika. O blizupomenskosti oz. paronimiji lahko govorimo pri istokorenskih besedah, iz iste besedotvorne družine, ki pa se kot pomenske različice ravno toliko ločujejo, da so v istem sobesedilu nezamenljive.

Paronimi so vse prepogosto vzrok normativno napačne rabe, ki izhaja iz nepoznavanja besedotvorne teorije, tj. iz nepoznavanja osnovnih besedotvornih tipov in besedotvornih pomenov. Paronimi so še posebej pogosti pri prevzetih istokorenskih in blizu- oz. podobnozvočnih leksemih.

4.5 Z izraznega vidika imamo tudi podobnozvočnice, ki zaradi podobnega izgovora in različnega pomena delujejo kot t. i. lažni prijatelji, npr. beseda 'pozor' v slovanskih jezikih.

5 Težko je, in verjetno bo z vedno večjo determinologizacijo še težje, razmejiti splošnouporabljano oz. tudi splošnosporazumevalno leksiko od terminologiziranega strokovnega izrazja.

5.1 Zaradi pomanjkanja različnih slovarjev se izkrivlja prava oz. dejanska podoba današnje leksike - navadno se ne ločuje natančno, kateri leksemi so novotvorbe in kateri leksemi so po daljšem času samo ponovno oživeli v rabi.

\section{Terminološke opombe s težnjo za natančnejše in jasnejše slovarske oznake}

Avtorica opozarja na poimenovalne različice, ki navadno niso povsem enakovredne in zato je pomembna njihova čimbolj natančna oz. enoumna uporaba - med najosnovnejšimi poimenovanji so zagotovo beseda, leksem in leksemska enota; avtorici je med naštetimi izrazi najsplošnejša in zato tudi najbolj nevtralna leksemska enota.

Izraz etimon avtorica uporablja kot 'osnovni in hkrati izvorni pomen leksema'. Izraz entiteta je po avtorici jeziko(slo)vna oznaka za pomensko-izrazno razmerje do predmetnosti oz. pojavnosti.

Avtorica opozarja na terminološki razločevalni opredelitvi pri ločevanju na$\underline{\text { ravnega in slovničnega spola (v hrv. spol : rod) in osebe v denotativnem pomenu }}$ nasproti osebi kot slovnični (glagolski) kategoriji (v hrv. oseba : lice).

Iz celotnega dela veje sporočilo, da slovaropisna vpetost med sistemom in aktualno rabo potrebuje ustvarjalno leksikološko delo, pri katerem je za leksikografa najlepša nagrada in zadostitev, da najde čimbolj optimalne odgovore oz. rešitve za sprotna leksikološka in leksikografska vprašanja.

Andreja Žele

Inštitut za slovenski jezik Frana Ramovša ZRC SAZU

Novi trg 2, 1000 Ljubljana

andreja@zrc-sazu.si 